4. Косило Н. В. Типологічні особливості українського та англійського натуралізму в порівняльному аспекті. ВІСНИК Житомирського державного університету імені Івана Франка. 2004, с. 135-138.

5. Ткачук М. П. Жанрова структура прози Івана Франка (бориславський цикл та романи 3 життя інтелігенції). Монографічне дослідження. Тернопіль, 2003. 384 с.

6. Франко І. Зібрання творів: у 50 т. К.: Наукова думка, 1976 - 1986. Т. 15: Повісті ті оповідання (1978 - 1982). 511 с.

DOI https://doi.org/10.30525/978-9934-26-073-5-1-33

\title{
ЦИКЛІЧНІСТЬ ЧАСУ ЯК ОСНОВОПОЛОЖНА КАТЕГОРІЯ ЗБІРКИ Б. ТОМЕНЧУКА «СЕЗОН НЕНАПИСАНИХ ВІРШІВ»
}

\author{
Міняйло С. А. \\ учитель української мови та літератури \\ Харківського ліцею № 141 \\ м. Харків, Україна
}

Поетична збірка «Сезон ненаписаних віршів» Богдана Томенчука $\epsilon$ четвертою у творчому доробку письменника. Проте, на жаль, на сьогодні немає грунтовних досліджень поезій цієї збірки митця, що й зумовлює актуальність нашої розвідки.

Циклічний час - одна 3 форм конкретизації художнього часу. Так, збірка «Сезон ненаписаних віршів» характеризується, перш за все, циклічністю, яка має два аспекти вияву: зовнішній, визначений об'єктивно-темпоральною фіксацією часового циклу; внутрішній, зумовлений психологічним фактором - індивідуально-суб'єктивним сприйняттям, відчуттям невпинного «колообігу» часу [1, с. 224]. I внутрішня, і зовнішня форми фіксації часоплину моделюють образи річного та добового циклів. Одним 3 найкращих проявів циклічного часу стає природній календар, що підтверджуються прикладами 3 творчості безлічі письменників, які торкалися цієї теми у своїх текстах. Особливою увагою користувалися пейзажні мотиви, у яких в найбільшій мірі зберігається єдність національної поетичної свідомості.

Перебіг часу у внутрішньому «я» ліричного героя має певні особливості. Якщо восени ми бачимо його таким, що проник у чимало таємниць буття, психіки («Та осінь світилася так горобинно», «Я в очах твоїх дотиком світла намалюю осінній мотив», «В покосі осіннього сіна», 
«Опале листя на воді...»), то зима («такі сніги навкруг, такі первісні луни») - це час міркувань, тиші і спогадів, що заполоняють душу ліричного героя. Зима зображується не лише порою холоду, а й певною мірою відображає осягнення ліричним героєм застиглості світу: «А місто за вікном підкреслено земне» [2, с. 73].

У поезіях збірки «Сезон ненаписаних віршів» Б. Томенчука ми не бачимо ліричного героя навесні. Можливо, це тому, що він заявляє про себе як про зрілу сформовану особистість, якій потрібно виговоритися чи висповідатися. А це найкраще робити в пору розважливу, притихлу, таку, як осінь. Осінь зображується в текстах у найрізноманітніших проявах, частіше через персоніфікацію: «Дощ визбирав тишу по краплі», «I хмари йшли, немов самотні вдови», «Крізь осінь, що стояла в наготі» [2, с. 81$]$.

Літній часопростір важливий для ліричного героя 3 погляду буяння природи. Прикладом чого можуть слугувати такі рядки: «Бажання твого найтугіша дуга -/ Як зойк серед нашого літа...» [2, с. 23 ]; «День спекотний безсило / Домлівав на межі» [2, с. 24], або «І ми за просторами світу... / Своє відсвятковуєм літо» [2, с. 40 ]. Подані віршорядки засвідчують, що літо приносить спокій ліричному герою.

Добовий цикл сприймається у поезіях як мікромодель циклічного часу, осмислюється в особистому просторі ліричного героя і характеризується двома образними схемами часообігу: бінарно-протиставною - базується на опозиції ранок/ніч i проєктує замкнений, обмежений, ущільнений рух часу по асоціативному «мікроколу»; чергувально-наступальною, що відтворює одвічний рух буття, а художній механізм цієї умовної схеми визначається швидкоплинним, стрибкоподібним або монотонним, уповільненим ритмом взаємозаміни ранку (ранків) / ночі (ночей) [1, с. 225]. В окремих поезіях Б. Томенчука наявний монотонний цикл зміни ранку / ночі, що втілює ідею вічності, зупиненого часу: «Його подих блукав / У волоссі і у подушках. / А під ранок чомусь / Чистим змістом зникав у верлібрах» [2, с. 64].

Зміна пір дня нерозривно пов'язана $з$ філософською категорією часу. У Б. Томенчука поширений мотив плинності світу через одночасне використання образів ранку, дня та вечора як окремих періодів доби. Перебуваючи в різних часових прошарках, ліричний герой заглиблюється у власний світ, тому внутрішнє відчуття хронотопу спричинює переживання часової безмежності: «Над плином часу й бильцями світань» [2, с. 5]; «Час чомусь обирає обтічність» [2, с. 33]; «Серед часів, немов серед води» [2, с. 91]. 
Наведені приклади дають підставу зробити висновок, що у поета феномен ночі з наскрізною концепцією циклічного часу певною мірою виступає опозицією до християнського тлумачення ночі як царства смерті, забуття, темряви. Тобто, можна говорити про те, що в поезії Б. Томенчука ніч протиставлясться світу реальному, зрозумілому, заданому, а світ нічних марень, явищ - повсякденній дійсності. Ліричний герой відчуває себе захищеним саме під покровом ночі. У цей час його надійно захищають янголи своїми крилами, а вдень він піддається різним негативним впливам: «В небі чомусь тільки тіні птахів, / Справжні лиш янгольські крила» [2, с. 43].

Отже, циклічність часу для Б. Томенчука - це основоположна категорія. Поезія підтверджує майстерність автора у змалюванні річного і добового циклів, насамперед, улюблених пір дня - вечора і ночі. За допомогою циклічного відтворення часу поет висвітлює різні емоційні стани ліричного героя, які підкреслюють психологічну заглибленість, філософську наповненість, алогічність настроїв. Це навіює читачеві широкі можливості трактування образів, робить їх символічними, розширює виражальні спроможності через утворення різноманітних асоціативних зчеплень.

\section{Література:}

1. Бондар Л. Художній час, простір і хронотоп у віршах українських авторів. Гуманітарна освіта у технічних вищих навчальних закладах. 2011. Вип. 23. С. 219-229.

2. Томенчук Б. Сезон ненаписаних віршів. Брустури: Дискурсус, 2015. $142 \mathrm{c}$. 